\title{
1984 année Diderot. Au regard de nos préoccupations : l'encyclopédiste
}

\section{Claude Lefébure}

\section{(2) OpenEdition \\ 1 Journals}

Édition électronique

URL : https://journals.openedition.org/tc/1000

DOI : $10.4000 /$ tc. 1000

ISSN : 1952-420X

Éditeur

Éditions de l'EHESS

\section{Édition imprimée}

Date de publication : 1 juin 1984

ISSN : 0248-6016

\section{Référence électronique}

Claude Lefébure, «1984 année Diderot. Au regard de nos préoccupations : l'encyclopédiste », Techniques \& Culture [En ligne], 3 | 1984, mis en ligne le 26 janvier 2006, consulté le 29 septembre 2022. URL : http://journals.openedition.org/tc/1000 ; DOI : https://doi.org/10.4000/tc.1000

Ce document a été généré automatiquement le 29 septembre 2022

Tous droits réservés 
1984 année Diderot. Au regard de nos préoccupations : l'encyclopédiste

Claude Lefébure 